ISSN (print): 2715-3177| ISSN (online): 2614-8102 Program Studi Ekonomi Syariah, STAI Auliaurrasyidin Tembilahan Journal Homepage: https://ejournal.stai-tbh.ac.id/index.php/al-muqayyad

\title{
Perkembangan Asuransi Syariah di Inggris
}

\begin{tabular}{|c|c|}
\hline Email & 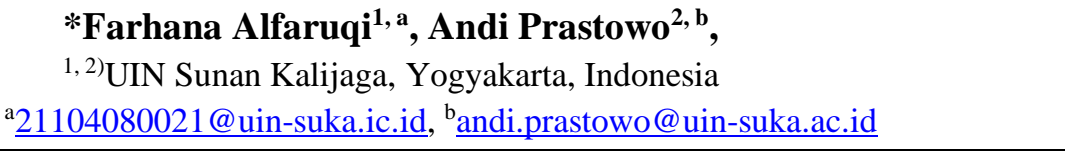 \\
\hline DOI: & Cara MensitasiArtikel ini: \\
\hline$\frac{\text { https://doi.org/10.469 }}{63 / \text { jam.v4i2.467 }}$ & $\begin{array}{l}\text { Alfaruqi, F., \& Prastowo, A. (2021). Perkembangan asuransi syariah di Inggris. } A L \text { - } \\
\text { Muqayyad, } 4 \text { (2), 128-133. https://doi.org/10.46963/jam.v4i2.467 }\end{array}$ \\
\hline
\end{tabular}

\begin{tabular}{|c|c|}
\hline \multirow[b]{2}{*}{$\begin{array}{l}\text { Keywords: } \\
\text { Insurance, Sharia, } \\
\text { United Kingdom }\end{array}$} & ABSTRACT \\
\hline & $\begin{array}{l}\text { Great Britain is a country where the majority of the population is non-Muslim, } \\
\text { but the development of Islamic banking and finance is very good. This is } \\
\text { evidenced by the operation of six full Islamic banks and sixteen banks that serve }\end{array}$ \\
\hline \multirow{4}{*}{$\begin{array}{l}\text { Kata Kunci: } \\
\text { Asuransi, Syariah, } \\
\text { Inggris }\end{array}$} & Islamic windows. Sukuk transactions for investors also increased as evidenced \\
\hline & $\begin{array}{l}\text { by increased demand on the London Stock Exchange with a total of } £ 51 \text { billion. } \\
\text { Likewise with takaful products, the UK reinsurance market that deals in Islamic }\end{array}$ \\
\hline & $\begin{array}{l}\text { finance. As one of the largest insurance markets in the world, and a leading } \\
\text { global center for wholesale insurance and reinsurance, the UK has the potential } \\
\text { to support the growth of the takaful business in the years to come. }\end{array}$ \\
\hline & $\mathbf{A B}$ \\
\hline InformasiArtikel: & gris Raya merupakan negara yang mayoritas penduduknya non muslim, \\
\hline \multirow{6}{*}{$\begin{array}{l}\text { Diterima: } \\
\text { 30/12/2021 } \\
\text { Direvisi: } \\
\text { - } \\
\text { Diterbitkan } \\
31 / 12 / 2021\end{array}$} & namun perkembangan perbankan dan keuangan syariah sangat baik. Hal ini \\
\hline & dibuktikan dengan beroperasinya enam bank syariah penuh dan enam belas \\
\hline & bank yang melayani Islamic windows. Transaksi sukuk untuk investor juga \\
\hline & meningkat yang dibuktikan dengan meningkatnya permintaan di London Stock \\
\hline & Exchenge dengan total $£ 51$ miliar. Begitu juga dengan produk takaful, pasar \\
\hline & relasuransi Inggris yang bertransaksi keuangan syariah. Sebagai salah satu \\
\hline \multirow{3}{*}{$\begin{array}{l}\text { *Corresponding } \\
\text { Author } \\
\text { author1@gmail.com }\end{array}$} & grosir dan reasuransi, Inggris memiliki potensi untuk mendukung pertumbuhan \\
\hline & bisnis takaful di tahun-tahun mendatang. \\
\hline & \\
\hline
\end{tabular}

\section{PENDAHULUAN}

Ancaman penganut neo-revivalis terhadap bank konvensional yang berbasis bunga mendorong didirikannya bank syariah menggunakan sistem bagi akibat di negaranegara Arab sang para investor Arab. Pesatnya perkembangan bank syariah pada negaranegara Arab serta meningkatnya kekayaan minyak negara-negara Arab mendorong perluasan usaha bagi bank syariah sampai ke kawasan Eropa diantaranya Inggris, Jerman, Prancis, Italia dan negara Eropa lainnya. Berasal beberapa negara pada Eropa, Inggris yang lebih siap menerima investasi dari negara Arab yang mempunyai kelebihan dana. Maka pada tahun 2004 berdirilah bank syariah pertama yang menggunakan konsep free interest menggunakan sistem profit and loss sharing (PLS). Pada tengah rakyat Inggris yang pluralis, bank syariah terus berkembang menggunakan positif dan menjadi sistem perbankan alternative. Kemajuan bank syariah tersebut dapat dilihat dari berdirinya bank-bank syariah yang sampai2015 berjumlah 6 bank umumsyariahserta16 bank konvensional yang menunjukkan layanan keuangan syariah. Hal ini menandakan 
Perkembangan Asuransi Syariah di Inggris

turunnya reputasi kapitalis di negara Inggris khususnya serta umumnya di Eropa. (Hendro dan Soleha, 2018:102).

Takaful merupakan cara lain Syariah compliant dengan asuransi konvensional. ad interim terdapat pertumbuhan yang cepat pada industri takaful di seluruh dunia, itu merupakan pada awal-nya tahap pada Inggris. (Eva Masrisfah,2015)

Inggris mencatat sejarah pada perkembangan bank syariah pada Eropa dan menjadi pionir di antara negara Eropa yang mengizinkan pengoperasian bank syariah keuangan Islam menggunakan sepenuhnya menggunakan tata cara syariah. Negara ini pula telah menandakan keberhasilan prinsip bank tanpa bunga yang pada awalnya tidak dapat diterima pada kalangan Barat serta menjawab pandangan negatif para pakar ekonomi terhadap bank syariah. (Roficoh dan Luluk Wahyu, 2018:121)

\section{METODE}

Metode penulisan bersifat studi pustaka. Informasi yang didapatkan dari berbagai literatur dan disusun berdasarkan hasil studi dari informasi yang diperoleh. Penulisan diupayakan saling terkait antara satu sama lain sesuai dengan topik yang dibahas. Data yang terkumpul dan diurutkan sesuai dengan topik kajian. Kemudian dilakukan penyusunan karya tulis berdasarkan data yang telah dipersiapkan secara logis dan sistematis. Teknik analisis data bersifat deskriptif dan argumentatif. Simpulan didapatkan setelah merujuk kembali pada rumusan masalah, tujuan penulisan, serta pembahasan. Simpulan ditarik mempresentasikan pokok bahasan karya tulis, serta didukung dengan saran praktis sebagai rekomendasi selanjutnya.

\section{HASIL DAN PEMBAHASAN}

\section{Sejarah Perkembangan Perbankan Syariah di Inggris}

Sejak pembentukan sistem pada akhir 1970-an dan awal 1980-an, Inggris telah menganut tren perbankan dan keuangan Islam. Pada tahun 1976, setelah Konferensi Internasional pertama tentang Ekonomi Islam yang diselenggarakan oleh Universitas King Abdul Aziz di Mekah, Arab Saudi, Yayasan Islam Leicester (Inggris) mendirikan Departemen Ekonomi Islam sebagai Pusat Penelitian Ekonomi Islam pertama. mata kuliah ekonomi Islam. Pada tahun 1977, Pusat Studi Internasional Ekonomi Islam di Universitas King Abdul Aziz mengikuti di belakang. Oleh karena itu pelopor ekonomi, perbankan, dan keuangan Islam seperti Nejattulah Sidqi, Umer Chapra, dan lain-lain menerbitkan karya-karya besar. Dalam perkara ini juga dilaksanakannya konferensi, seminar tentang topik tersebut bekerjasama dengan Islamic Development Bank (IDB). The Islamic Research and Training Institute (IRTI) dan Universitas Loughborough.

Sebuah penelitian menunjukkan bahwa Inggris merupakan negara menggunakan bank pada antara negara-negara Barat lainnya, Muslim ialah yang paling poly. di Inggris, beliau mempunyai Pendirian Bank Islam Inggris (IBB)/2004, Investasi Islam Eropa Bank (EIIB)/2005, Bank London serta Timur Tengah (BLME)/2007, Qatar Islamic Bank UK (QIBUK), Gedung Keuangan Eropa, Gatehouse/2008, serta Bank Islam Abu Dhabi

\section{Al-Muqayyad}

Vol 4 No 2 (2021) 
(ADIB-UK)/2013.. ada 17 bank Lainnya seperti Barclays, Royal Bank of Scotland serta Lloyds Banking group memiliki unit bisnis aturan syariah.

Bank Islam Inggris mempunyai aset sebesar US\$18 miliar (12 miliar) British Pound) melebihi aset bank syariah seperti Pakistan, Bangladesh, Turki serta Mesir. Hal ini juga didukung oleh 55 universitas dan forum pendidikan Lainnya yang telah menerima pendidikan keuangan Islam di Inggris. kuantitas Lebih asal negara lain. (Ahmad, 2015:54)

Dari sumber laporan International Financial Services London (IFSL) di awal tahun 2010, perkembangan Inggris menjadi pusat keuangan Islam dalam beberapa tahun terakhir sangat didukung sang pemerintah. Dukungan pemerintah antara lain artinya keleluasaan pajak bagi kredit tempat tinggal dan membuat perdagangan menjadi lebih praktis. (Ahmad, 2015:55)

Dukungan kebijakan pemerintah Inggris akan keuangan Islam menempatkan pelayanan syariah mirip layanan konvensional. Inggris menduduki peringkat 8 pada aset perbankan syariah di semua global meski demikian syariah tidak berasal dari Inggris akan tetapi keuangan syariah telah menemukan tempatnya pada Inggris (Sir Andrew Cahn). Keuangan syariah dapat bertahan asal krisis kredit serta resesi lebih baik berasal bank lainnya sebab adanya larangan investasi pada aset yang berisiko, mirip halnya sub-prime morigages. (Puspitadewi, 2010:21-22)

Selanjutnya pada tahun 1983 perusahaan Takaful UK didirikan sebagai anak perusahaan dari DMI untuk memenuhi kebutuhan umat Islam yang berada di Inggris dengan menawarkan kepada mereka kesempatan investasi syariah yang disediakan oleh Takaful S.A di Luxembourg. Pendirian Takaful diperuntukkan bagi mereka yang berpendapat bahwa produk keuangan terutama asuransi konvensional terkontaminasi oleh riba atau bunga. Takaful UK yang beroperasi di Birmingham juga menawarkan jasa keuangan syariah yang tersedia pada spektrum yang luas oleh penyedia produk sebagai tambahan penawaran pelayanan Takaful yang dilakukan oleh Takaful S.A di Luxembourg.

Takaful Dengan peluncuran Asosiasi Asuransi Syariah London atau Islamic Insurance Association of London (IIAL) pada tahun 2015, Inggris telah siap mengambil andil dalam pasar takaful global secara lebih aktif. Lloyd, Chartered Insurance Institute (CII), the London Market Group (LMG), International Association Insurance Brokers London (LIIBA) dan The City UK telah menjadi anggota asosiasi dari IIAL. IIAL dibentuk untuk mendukung kinerja pasar reasuransi Inggris yang bertransaksi dengan sistem keuangan syariah. Sebagai salah satu pasar asuransi terbesar di dunia, dan pusat terkemuka untuk asuransi dan reasuransi global, Inggris memiliki potensi dalam mendukung pertumbuhan bisnis takaful di tahun-tahun mendatang. Sektor takaful Inggrismembuat strategi percepatan pada Maret 2015 dengan melakukan perkumpulan bersama XL Grup dan Cobalt Underwriting yang telah meluncurkan produk syariah pertama yang tersedia di Lloyd London. Sebelumnya, Willis dalam hubungannya dengan 
Perkembangan Asuransi Syariah di Inggris

Cobalt Underwriting, meluncurkan solusi asuransi syariah real estat komersial Inggris pertama. Lloyd, yang merupakan pasar asuransi di London membuka kantor di Dubai dan juga melakukan pembicaraan dengan regulator pasar Malaysia untuk mendirikan sebuah kantor yang didedikasikan untuk takaful. (Hendro dan Sholeha, 2018:107)

\section{Pandangan Warga Inggris terhadap Lembaga Keuangan Syariah}

Pada bulan Februari 2014 Muslim Village melaporkan hasil survei suatu lembaga independen Europe tentang pandangan warga Inggris terhadap bank Syariah. Lembaga survei independen tersebut melakukan survey kepada 300 responden Muslim dan non Muslim yang tersebar di seluruh Inggris dengan mewawancarai mereka via telepon pada Agustus 2013. Hasil survey tersebut menyatakan bahwa Dua pertiga responden merupakan nasabah Islamic Bank of Britain (IBB). Baik Muslim maupun non Muslim. Hasil survei menunjukkan $66 \%$ responden percaya sistem keuangan syariah cocok untuk masyarakat ekonomi barat seperti Inggris $65 \%$ responden paham cara kerja perbankan syariah berbeda dengan cara kerja perbankan konvensional $60 \%$ responden setuju perbankan syariah relevan untuk semua agama 57\% responden juga tahu perbankan syariah memberi bagi hasil, bukan bunga. Survey tersebut menyimpulkan bahwa warga Inggris percaya sistem keuangan Syariah aplikatif untuk semua agama. Mereka juga percaya bahwa sistem keuangan Syariah dapat diimplementasikan masyarakat ekonomi modern di negara barat. Hasil survei ini menjadi prospek baik bagi pertumbuhan perbankan syariah di Inggris. IBB memperkirakan ada sekitar satu juta Muslim Inggris yang membutuhkan jasa tabungan syariah. hasil ini pula timbul waktu sektor keuangan syariah Inggris mulai berkembang, termasuk menggunakan diluncurkannya sukuk sebagai instrumen investasi syariah.

Tentang persepsi nasabah lembaga keuangan syariah pada Inggris menunjukkan bahwa lebih banyak didominasi responden menganggap forum Keuangan syariah menjadi entitas dengan ciri spesial dan karakteristik yang tidak sama menggunakan lembaga Keuangan konvensional. Para responden juga menduga forum Keuangan syariah menjadi sistem bebas bunga yang bisa melayani peran dan tugas yang pada warga khususnya, yang mereka anggap bank syariah sebagai lembaga keuangan yang ditandai dengan tata cara-istiadat etika. Selain itu terdapat mufakat awam di kalangan responden bahwa bank syariah wajib beroperasi sesuai menggunakan hukum Syariah, yang sebagian akbar berdasarkan pada prinsip bagi akibat atau profit and loss sharing (PLS). (Hendro dan Sholeha, 2018: 105-106)

Dari penelitian Independen 2Europe, Saeed akbar dan Humayon pada atas, dapat diduga bahwa Inggris berbagi pasar keuangan syariah sebetulnya ditimbulkan sang laba ekonomi bukan karena landasan filosofinya. Dugaan ini dapat dibuktikan dari pernyataan mantan Perdana Menteri Gordon Brown pada tahun 2008, "We are looking for the benefits of investment including the ones from Middle East countries. Islamic banking is one of the evidences of it". Selain itu Perdana Menteri David Cameron di 29 Oktober 2013 bersedia meresmikan instrumen investasi Sukuk buat masyarakat Muslim Inggris

\section{Al-Muqayyad}

Vol 4 No 2 (2021) 
dalam forum Ekonomi Islam global (WIEF). Hal ini karena ada sisi keuntungan ekonominya yg akan berdampak pada Negara Inggris. (Fuji Pratiwi, 2015)

Hal ini terutama disebabkan oleh beratnya persaingan pasar dari bank-bank konvensional yang telah usang eksis, di mana para nasabah menuntut pengembalian sebanding dari deposito mereka. Selain itu kurangnya kerangka peraturan, keahlian serta mekanisme baku serta alat-alat pada praktik perbankan syariah. Menggunakan demikian, hal yang terpenting bagi bank syariah serta konvensional yang menunjukkan produkproduk syariah menerapkan hukum syariah dalam praktik perbankan. karena sesuai Studi asal Meera serta Larbani menegaskan bahwa pengoperasian model keuangan syariah yang mirip dengan perbankan konvensional menjadi penghambat pencapaian tujuan hukum Islam. (Irvani, Ahmad, 2016:125-126)

\section{SIMPULAN}

Sejak pembentukan sistem pada akhir 1970-an dan awal 1980-an, Inggris telah menganut tren perbankan dan keuangan Islam. Pada tahun 1976, setelah Konferensi Internasional pertama tentang Ekonomi Islam yang diselenggarakan oleh Universitas King Abdul Aziz di Mekah, Arab Saudi, Yayasan Islam Leicester (Inggris) mendirikan Departemen Ekonomi Islam sebagai Pusat Penelitian Ekonomi Ekonomi Islam pertama. mata kuliah ekonomi Islam. Sebuah penelitian menunjukkan bahwa Inggris merupakan negara menggunakan bank pada antara negara-negara Barat lainnya, Muslim ialah yang paling poly. Bank Islam Inggris mempunyai aset sebesar US\$18 miliar (12 miliar) British Pound) melebihi aset bank syariah seperti Pakistan, Bangladesh, Turki serta Mesir. Hal ini juga didukung oleh 55 universitas dan forum pendidikan Lainnya yang telah menerima pendidikan keuangan Islam di Inggris. kuantitas Lebih asal negara lain. Dari sumber laporan International Financial Services London (IFSL) di awal tahun 2010, perkembangan Inggris menjadi pusat keuangan Islam dalam beberapa tahun terakhir sangat didukung sang pemerintah.

Pada tahun 1983 perusahaan Takaful UK didirikan sebagai anak perusahaan dari DMI untuk memenuhi kebutuhan umat Islam yang berada di Inggris dengan menawarkan kepada mereka kesempatan investasi syariah yang disediakan oleh Takaful S.A di Luxembourg. Pendirian Takaful diperuntukkan bagi mereka yang berpendapat bahwa produk keuangan terutama asuransi konvensional terkontaminasi oleh riba atau bunga. Takaful Dengan peluncuran Asosiasi Asuransi Syariah London atau Islamic Insurance Association of London (IIAL) pada tahun 201529, Inggris telah siap mengambil andil dalam pasar takaful global secara lebih aktif. Lloyd, Chartered Insurance Institute (CII), the London Market Group (LMG), International Association Insurance Brokers London (LIIBA) dan The City UK telah menjadi anggota asosiasi dari IIAL. IIAL dibentuk untuk mendukung kinerja pasar reasuransi Inggris yang bertransaksi dengan sistem keuangan syariah.

Pada bulan Februari 2014 Muslim Village melaporkan hasil survey suatu lembaga independen 2Europe tentang pandangan warga Inggris terhadap bank Syariah. Lembaga 
Perkembangan Asuransi Syariah di Inggris

survei independen tersebut melakukan survey kepada 300 responden Muslim dan non Muslim yang tersebar di seluruh Inggris dengan mewawancarai mereka via telepon pada Agustus 2013.Tentang persepsi nasabah lembaga keuangan syariah pada Inggris menunjukkan bahwa lebih banyak didominasi responden menganggap forum Keuangann syariah menjadi entitas dengan ciri spesial dan karakteristik yang tidak sama menggunakan lembaga Keuangan konvensional. Dari penelitian Independen Europe, Saeed akbar dan Humayon pada atas, dapat diduga bahwa Inggris berbagi pasar keuangan syariah sebetulnya ditimbulkan sang laba ekonomi bukan karena landasan filosofinya. Dugaan ini dapat dibuktikan dari pernyataan mantan Perdana Menteri Gordon Brown pada tahun 2008, "We are looking for the benefits of investment including the ones from Middle East countries. Islamic banking is one of the evidences of it”.

\section{REFERENSI}

Ahmad, D. (2015). Interrelasi Ekonomi, Sosial, Dan Politik dalam Perkembangan Lembaga Keuangan Syariah di Inggris. Laporan Penelitian, 54-55. Fakultas Ekonomi dan Bisnis Islam, Perbankan Syariah, IAIN Purwokerto.

Irvani, A. (2016). Inggris sebagai Sentral Keuangan Islam di Barat. Asy Syar'iyyah: Jurnal Ilmu Syari'ah dan Perbankan Islam, 1(1), 120-143.

Lisa, H, \& Sholeha, S. (2018). Perkembangan asuransi syariah di negara muslim minoritas (Studi Kasus: Inggris)." AL-Muqayyad,1(2), 99-111. https://doi.org/10.46963/jam.v1i2.8

Masrifah, E. "Analisis pengembangan produk Takaful Mikro Sakinah: Studi kasus pada Takmin Working Group, Bogor. Skripsi, UIN Jakarta.

Pratiwi, F (2014). Keuangan Syariah Cocok Diterapkan di Ekonomi Barat. http://www.republika.co.id/berita/ekonomi/syariah-ekonomi/14/02/08/n0n65ringgris-keuangan-syariah-cocok-diterapkan-di-ekonomi-barat

Puspitadewi, A. (2010). Analisis Perbedaan Kinerja Keuangan Bank Syariah Di Indonesia dengan Bank Syariah Di Inggris (Analisis Rasio Keuangan Tahun 2006-2008).

Roficoh, L. W. (2018). Tinjauan empirik perkembangan sistem ekonomi syariah di Eropa." Ijtihad: Jurna Hukum dan Ekonomi Islam 12.1 (2018): 44-62. http://dx.doi.org/10.21111/ijtihad.v12i1.2547 